
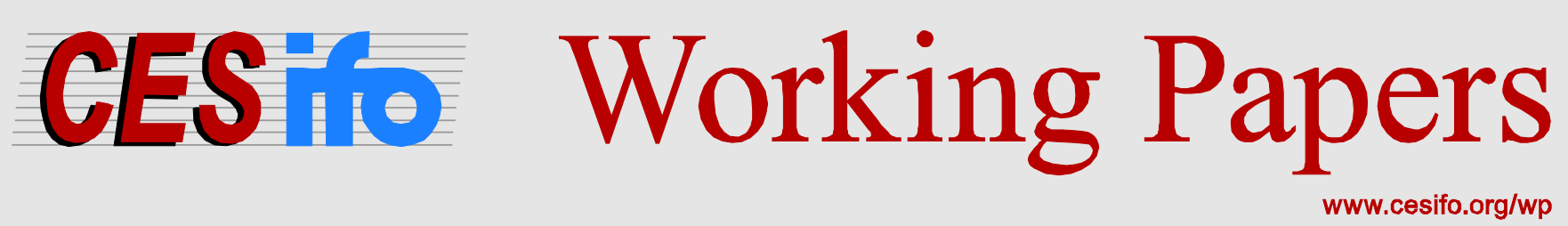

\title{
Polarized Education Levels and Civil War
}

\author{
Gustavo Javier Canavire-Bacarreza \\ Michael Jetter \\ Alejandra Montoya-Agudelo
}

\author{
CESIFO WORKING PAPER NO. 6267 \\ CATEGORY 6: FisCAL POLICY, MACROECONOMICS AND GROWTH \\ DECEMBER 2016
}

An electronic version of the paper may be downloaded

- from the SSRN website:

- from the RePEc website:

- from the CESifo website:

wWw.SSRN.com

Www.RePEc.org

www.CESifo-group.org/wp 


\title{
Polarized Education Levels and Civil War
}

\begin{abstract}
This paper suggests that societies exhibiting a large degree of educational polarization among its populace are systematically more likely to slip into civil conflict and civil war. Intuitively, political preferences and beliefs of highly educated citizens are likely to differ fundamentally from those of uneducated citizens. We propose an index of educational polarization and test its predictive power in explaining the likelihood of civil conflict and civil war, analyzing 146 countries (equivalent to over 93 percent of the world population) from 1950 to 2014. Our results produce strong evidence for a positive, statistically powerful, and economically sizeable relationship. In our benchmark estimation, a one standard deviation increase in educational polarization is associated with a 4.6 and 3.8 percentage point rise in the chances of civil conflict and civil war, respectively. These results are robust to the inclusion of the conventional control variables, country-fixed effects, and country-specific time trends.
\end{abstract}

JEL-Codes: D630, D740, I240, O150.

Keywords: civil conflict, civil war, educational polarization, panel data.

\author{
Gustavo Javier Canavire-Bacarreza \\ School of Economics and Finance \\ Universidad EAFIT \\ Colombia / Medellín \\ geanavir@eafit.edu.co
}

\author{
Michael Jetter* \\ University of Western Australia \\ 35 Stirling Highway \\ Australia - Crawley 6009, WA \\ mjetter7@gmail.com
}

\author{
Alejandra Montoya-Agudelo \\ School of Economics and Finance \\ Universidad EAFIT \\ Colombia / Medellín \\ alejamontoyaa@gmail.com
}

*corresponding author

December 14, 2016

We thank the Center for Research in Economics and Finance (CIEF) at the Universidad EAFIT for its support. All remaining errors are our own. 


\section{Introduction}

A polarized society is more likely to experience civil unrest, as recently pointed out in a series of papers by Joan-María Esteban and Debraj Ray (e.g., see Esteban and Ray, 1994, 1999, 2008, 2011; Esteban et al., 2012, but also Reynal-Querol and Montalvo, 2005). "[T]he phenomenon of polarization is closely linked to the generation of tensions, to the possibilities of articulated rebellion and revolt, and to the existence of social unrest in general" (Esteban and Ray, 1994, p.820)." Similarly, Collier and Hoeffler (2004, p.571) argue that "the source of inter-group tension is not diversity but polarization".

In particular, polarization along ethnic or religious dimensions has been found to matter (e.g., see Bhavnani and Miodownik, 2009, Klasnja and Novta, 2014, Reynal-Querol and Montalvo, 2005, Montalvo and Reynal-Querol, 2010, or Bosker and de Ree, 2014). Extending and complementing this literature, the following pages introduce educational polarization (EduP from hereon) as a meaningful predictor of civil conflict and civil war. What is our hypothesis based on, i.e., why would educational polarization matter? In the most general sense, common education levels can represent one "identity" along which unsatisfied citizens can organize themselves, similar to ethnicity or religion. A populace that is sharply divided among highly educated citizens on the one end and mostly uneducated citizens on the other end is more likely to hold fundamentally different preferences and beliefs, in addition to their understanding of how society should operate and what governments should do.

Recent popular examples can be found in the "Brexit" movement in the United Kingdom (UK) or the presidential election process of 2016 in the United States (US). In the UK, 27 of the 30 areas with the fewest graduates voted lo leave the European Union (BBC News, 2016), whereas the vast majority of university graduates was voting to remain. ${ }^{1}$ Such fundamental differences along the lines of educational attainment also became apparent in the 2016 US presidential elections. The election revealed a sharp contrast in preferences between those with little formal education (voting largely for Trump) and those with a college degree (voting largely for Clinton). ${ }^{2}$

\footnotetext{
${ }^{1}$ Those with only secondary education or a similar degree were more likely to support "Brexit" (The Telegraph, 2016). Only three out of 35 areas in which more than half of the residents have a degree voted to leave the European Union.

${ }^{2}$ These voting differences along the lines of education have been documented and discussed on numerous
} 
Luckily, we did not observe a civil conflict erupt in either of these two countries, although rising violence has been well-documented, especially during and after the US election campaign (e.g., see Okeowo, 2016, Lanyon, 2016, or Nagesh, 2016). But history has also shown us a number of cases where countries exhibiting largely polarized education levels within society eventually slid into civil conflict or even civil war. In general, if $E d u P$ is substantial, individuals with very little education are easier marginalized in terms of political and economic rights and opportunities. This can express itself in political power, as well as job opportunities and wages. Such discrepancies define political outcomes and can give rise to grievances.

For instance, Stewart et al. (2002); Stewart (2005) presents nine illustrative cases where inequalities between groups have led to political instability, and in some cases civil wars. Almost all of them feature educational differences as a determining factor. For example, in Sri Lanka the Tamil were favored by the British colonial administration, receiving relatively privileged access to education and university places. When the Sinhalese majority gained power, they appealed for equalizing policies, such as educational quotas on university access. These actions eventually provoked the Tamils to start a civil war seeking political independence in the 1980s.

Other examples can be found in South Africa under Apartheid, where state expenditure on education per white student was 14 times the expenditure per black student in 1980. The resulting educational polarization, combined with economic factors, led to an armed rebellion in 1976 (Stewart, 2005). Similarly, the Sudanese civil war was in large part caused by the inadequate provision of educational resources by the state. Historically, a more general expression of social tensions along the lines of education levels can be found in book burnings and organized violence targeted at scholars and academics (e.g., in 210 BC China, Christian burnings in AD 325, Nazi Germany).

This paper first derives an index of $E d u P$ and then provides empirical evidence for a strong relationship between $E d u P$ and the incidence of civil conflict and civil war. Using data for 146 countries (equivalent to over 93 percent of the world population) from 1950 to 2014, we find a systematically positive link that is meaningful both in statistical and economic terms. To be clear, the goal of our paper is not to argue that other forms of polarization, such as along ethnic or religious dimensions, do not matter. Rather, we posit that EduP can create an environment occasions. For examples, see Puglise (2016), Peters et al. (2016), and Kirk and Scott (2016). 
in which civil conflict becomes more likely.

Our work aims to contribute to two distinct streams of literature. First, we aim to improve our understanding of the conditions under which civil conflicts and civil wars are likely to erupt. The closest study to ours is developed by Østby (2008), who explores social polarization in terms of several economic and social aspects (including education) in the context of civil war onset. Her index considers years of education and is based on two artificial groups given by the mean. Our analysis goes deeper, deriving a more precise index for $E d u P$ by incorporating four distinct levels of educational attainment. We also consider country fixed effects, thereby controlling for any time-invariant unobservables on the country level, and a substantially larger sample. ${ }^{3}$ Second, we aim to pull EduP into the spotlight as an important societal factor that has previously been neglected. Thus, studies that analyze political developments per se, and political violence specifically, may find it useful to consider $E d u P$, both in terms of theoretic modelling and empirical analyses.

The paper proceeds with introducing a measure of $E d u P$, followed by a description of the data and the empirical methodology in Section 3. Section 4 presents our benchmark findings, whereas Section 5 discusses a series of robustness checks and extensions. Section 6 concludes with a brief discussion.

\section{A Polarization Index of Educational Attainment Levels}

\subsection{Construction of the Index}

The first contribution of this paper consists in deriving a polarization index for educational attainment on the country level. We access the database introduced by Barro and Lee (2013) for information on the population shares of four distinct categories of educational attainment for everybody over the age of 25 and under the age of 60: no schooling, complete primary schooling, complete secondary schooling, and completed tertiary schooling. Barro and Lee (2013) feature this information for 146 countries on a five year basis, beginning in 1950. This gives us 13 time periods $(1950-1954,1955-1959, \ldots, 2010-2014)$. Note that our results are virtually

\footnotetext{
${ }^{3}$ Østby (2008) analyzes 36 developing countries between the years 1986 to 2004, including 519 observations. Our full sample employs 1,897 observations and 1,240 observations after including all relevant control variables.
} 
identical when using the entire population (up to the age of 99) or when using seven categories: no schooling, some primary schooling, complete primary schooling, some secondary schooling, complete secondary schooling, some tertiary schooling, and completed tertiary schooling.

Our strategy to create the EduP index is based on Apouey (2007) who explores polarization within ordinal variables. Given four distinct levels of education, we consider education as an ordinal variable because a priori it is not clear how much education is added when moving from no schooling to primary schooling, as opposed to moving from completed secondary to completed tertiary schooling, for example. This becomes even clearer when considering a global sample, as every country features different educational structures. Thus, our index is median-based and independent of a cardinalizaton process, avoiding the problem of assigning a scale to calculate the mean.

In particular, with $c$ categories (where $1 \leq c \leq 4$ ) the index takes on the following form for country $i$ in the five-year period $t$ :

$$
P_{i t}=1-\frac{2^{\alpha}}{C-1} \sum_{c=1}^{C-1}\left|F_{c i t}-\frac{1}{2}\right|^{\alpha},
$$

where $F_{c i t}$ denotes the cumulative proportion of people in category $c$, country $i$, and period $t$. $C$ represents the total number of categories, in our case four. Following Apouey (2007, p.885), " $\alpha$ reflects the importance that is given to the median category" and we choose a value of 1.58 , as recommended when $C=4$ (equivalent to $\frac{\ln (4)-\ln (3)}{\ln (2)}$, see Table I in Apouey, 2007). ${ }^{4}$ The index is continuous and, in order to facilitate interpretation, we re-scale it so it can reach a maximum value of one.

Intuitively, if everybody shares the same level of education (e.g., everybody possesses complete secondary education), the index equals zero. If half of the populace exhibits no formal education, but the other half has completed tertiary education, the index equals one. In general, the index increases when the proportion of people at extremes increases or if the shares around the median category decrease.

\footnotetext{
${ }^{4}$ Intuitively, $\alpha=1.58$ ensures that the polarization index takes on the value of $\frac{1}{2}$ when the distribution is uniform. We refer to Apouey (2007) for a more detailed discussion.
} 


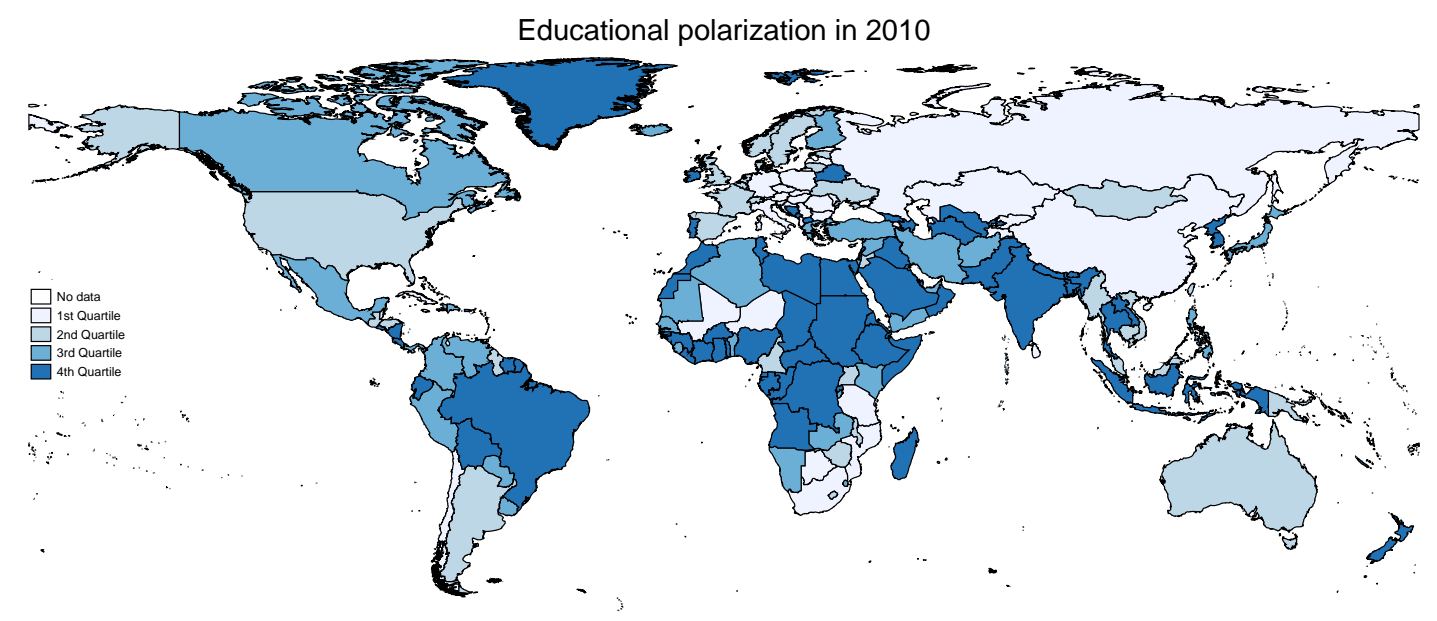

Figure 1: Educational polarization in 2010, where darker coloring indicates larger levels of polarization.

\subsection{Countries With Large Educational Polarization}

To provide an intuition of educational polarization around the world, Figure 1 maps the index for all 146 countries available in the 2010-2014 period. The largest degrees of polarization are reached in Pakistan and India with values of 0.46 and 0.39 , respectively. As it happens, both countries have experienced not only civil conflict (25 or more battle-related deaths in a given year) between 2010 and 2014, but also civil war (1,000 or more battle-related deaths). In general, educational attainment is much more polarized in the Middle East, Central African countries, and South America.

Table 1 presents some basic correlations of the EduP index with other prominent countrylevel characteristics, such as years of schooling, income levels, the degree of democracy, as well as ethnic and religious polarization indices. We will introduce these variables formally (with respective sources) in the following section. It is interesting, and maybe somewhat surprising, to see that large $E d u P$ particularly occurs in richer countries with better schooling. Further, other dimensions of societal polarization, such as by ethnicity or religion, are not related to $E d u P$.

To get a better understanding of which countries tend to exhibit large $E d u P$ levels, Table 2 presents results from regressing $E d u P$ on the respective variables. Columns (1) to (5) present results from pooled regressions, whereas column (6) introduces country-fixed effects. It is interesting to see that ethnic and religious polarization are not related to $E d u P$ (column 5), but 
Table 1: Correlations between $E d u P$ and other prominent country-level variables. Sample: 780 observations (13 observations for 60 countries).

\begin{tabular}{|c|c|c|c|c|c|c|}
\hline Variables & $\begin{array}{l}\text { Educational } \\
\text { polarization }\end{array}$ & Schooling & $\operatorname{Ln}(\mathrm{GDP} /$ cap $)$ & Polity & $\begin{array}{c}\text { Ethnic } \\
\text { polarization }\end{array}$ & $\begin{array}{c}\text { Religious } \\
\text { polarization }\end{array}$ \\
\hline Educational polarization & 1.000 & & & & & \\
\hline Schooling & 0.206 & 1.000 & & & & \\
\hline Ln(GDP/cap) & 0.231 & 0.752 & 1.000 & & & \\
\hline Ln(population size) & 0.067 & 0.089 & 0.079 & 1.000 & & \\
\hline Polity & -0.004 & 0.586 & 0.482 & 1.000 & & \\
\hline Ethnic polarization & -0.008 & -0.055 & -0.101 & -0.060 & 1.000 & \\
\hline Religious polarization & -0.083 & -0.018 & 0.018 & -0.042 & 0.282 & 1.000 \\
\hline
\end{tabular}

large and less democratic nations are those with larger EduP. (Note that since information on ethnic and religious polarization levels are only available once per country, these variables fall out in the fixed effects estimation.)

Although researchers have created alternative measures of educational inequality, (e.g., Thomas et al., 2001, Castelló and Doménech, 2002, or Ferreira and Gignoux, 2014), few studies have explicitly considered educational polarization or, more generally, the ordinal nature of education (as discussed, Østby, 2008, is a notable exception). ${ }^{5}$ This is particularly the case when considering potential drivers of civil conflict and civil war.

\section{$3 \quad$ Data and Methodology}

\subsection{Data}

All our data come from standard sources in the associated literature, as summarized in Table 3. Our analysis focuses on explaining two standard definitions of large-scale organized violence on the country level: civil conflicts, which are characterized by at least 25 battle-related deaths in a given year, and civil wars, corresponding to country-year observations that witness at least 1,000 battle-related deaths.

\footnotetext{
${ }^{5}$ For example, educational inequality has been analyzed (e.g., by creating a Gini index) or closely related proxies, such as the standard deviation of the years of schooling. In this context, Morrisson and Murtin (2013) compare differences in income inequality to educational inequality between 1870 and 2010, concluding the latter has decreased markedly since 1870 , whereas income inequality has increased.
} 
Table 2: Results from OLS regressions, predicting educational polarization. All variables constitute 5-year averages.

\begin{tabular}{|c|c|c|c|c|c|c|}
\hline & $(1)$ & $(2)$ & $(3)$ & (4) & $(5)$ & $(6)$ \\
\hline \multicolumn{7}{|c|}{ Dependent variable: Educational polarization } \\
\hline Schooling & $\begin{array}{c}0.006^{* * *} \\
(0.001)\end{array}$ & $\begin{array}{l}0.004^{*} \\
(0.002)\end{array}$ & $\begin{array}{c}0.003 \\
(0.002)\end{array}$ & $\begin{array}{c}0.004 \\
(0.003)\end{array}$ & $\begin{array}{c}0.006 \\
(0.004)\end{array}$ & $\begin{array}{c}0.006 \\
(0.004)\end{array}$ \\
\hline $\operatorname{Ln}(\mathrm{GDP} / \mathrm{cap})$ & & $\begin{array}{c}0.009 \\
(0.006)\end{array}$ & $\begin{array}{l}0.011^{*} \\
(0.007)\end{array}$ & $\begin{array}{l}0.014^{*} \\
(0.008)\end{array}$ & $\begin{array}{c}0.001 \\
(0.013)\end{array}$ & $\begin{array}{l}-0.018 \\
(0.012)\end{array}$ \\
\hline Ln(Population size) & & & $\begin{array}{l}0.005^{*} \\
(0.003)\end{array}$ & $\begin{array}{c}0.004 \\
(0.003)\end{array}$ & $\begin{array}{l}0.007^{*} \\
(0.004)\end{array}$ & $\begin{array}{c}0.086^{* * *} \\
(0.015)\end{array}$ \\
\hline Polity & & & & $\begin{array}{c}-0.002^{* * *} \\
(0.001)\end{array}$ & $\begin{array}{l}-0.001 \\
(0.001)\end{array}$ & $\begin{array}{c}-0.002^{* *} \\
(0.001)\end{array}$ \\
\hline Ethnic polarization & & & & & $\begin{array}{c}0.014 \\
(0.025)\end{array}$ & \\
\hline Religious polarization & & & & & $\begin{array}{l}-0.013 \\
(0.018)\end{array}$ & \\
\hline Country-fixed effects & & & & & & yes \\
\hline \# of countries & 146 & 128 & 127 & 127 & 74 & 127 \\
\hline \# of time periods & 13 & 13 & 13 & 13 & 13 & 13 \\
\hline$N$ & 1,897 & 1,535 & 1,503 & 1,311 & 768 & 1,311 \\
\hline Adjusted $R^{2}$ & 0.042 & 0.064 & 0.068 & 0.059 & 0.052 & 0.487 \\
\hline
\end{tabular}

Notes: Standard errors clustered on the country level are displayed in parentheses. ${ }^{*} p<0.10,{ }^{* *} p<0.05,{ }^{* * *}$ $p<0.01$. 
Table 3: Summary statistics of main variables.

\begin{tabular}{|c|c|c|c|c|c|}
\hline Variable & $\begin{array}{c}\text { Mean } \\
(\text { Std. Dev.) }\end{array}$ & $\begin{array}{l}\text { Min. } \\
(\operatorname{Max} .)\end{array}$ & $\mathrm{N}$ & Source $^{a}$ & Description (if necessary) \\
\hline \multicolumn{6}{|c|}{ Dependent variables } \\
\hline $\begin{array}{l}\text { Conflict } \\
(25+\text { deaths })\end{array}$ & $\begin{array}{c}0.19 \\
(0.39)\end{array}$ & $\begin{array}{c}0 \\
(1)\end{array}$ & 1,897 & UCDP & $\begin{array}{l}=1 \text { if at least } 1 \text { year with } \\
25+\text { battle-related deaths }\end{array}$ \\
\hline $\begin{array}{l}\text { War } \\
(1,000+\text { deaths })\end{array}$ & $\begin{array}{c}0.13 \\
(0.34)\end{array}$ & $\begin{array}{c}0 \\
(1)\end{array}$ & 1,897 & UCDP & $\begin{array}{l}=1 \text { if at least } 1 \text { year with } \\
1,000+\text { battle-related deaths }\end{array}$ \\
\hline \multicolumn{6}{|c|}{ Variable of interest } \\
\hline $\begin{array}{l}\text { Educational } \\
\text { polarization }\end{array}$ & $\begin{array}{c}0.17 \\
(0.09)\end{array}$ & $\begin{array}{c}0 \\
(0.54)\end{array}$ & 1,897 & $\mathrm{~B} \& \mathrm{~L}$ & $\begin{array}{l}\text { Educational polarization index } \\
\text { (see section } 2 \text { ) }\end{array}$ \\
\hline \multicolumn{6}{|l|}{ Control variables } \\
\hline Schooling & $\begin{array}{l}5.06 \\
(3.28)\end{array}$ & $\begin{array}{c}0 \\
(13.42)\end{array}$ & 1,897 & B\&L & Years of schooling \\
\hline GDP/cap & $\begin{array}{c}8.73 \\
(13.11)\end{array}$ & $\begin{array}{c}0.10 \\
(82.88)\end{array}$ & 1,313 & Maddison & $\begin{array}{l}\text { GDP/capita in thousand US\$, } \\
\text { applying the natural logarithm }\end{array}$ \\
\hline Population size & $\begin{array}{c}33.05 \\
(118.91)\end{array}$ & $\begin{array}{c}0.06 \\
(1,350.84)\end{array}$ & 1,578 & Maddison & $\begin{array}{l}\text { Population size in million, } \\
\text { applying the natural logarithm }\end{array}$ \\
\hline Oil production & $\begin{array}{c}19.29 \\
(64.53)\end{array}$ & $\begin{array}{c}0 \\
(603)\end{array}$ & 1,513 & Ross & $\begin{array}{l}\text { Oil production in million metric } \\
\text { tons, applying the natural } \\
\text { logarithm }\end{array}$ \\
\hline Polity & $\begin{array}{l}1.28 \\
(7.48)\end{array}$ & $\begin{array}{l}-10 \\
(10)\end{array}$ & 1,453 & Polity IV & $\begin{array}{l}\text { Variable polity2, ranging from }-10 \\
\text { (total autocracy) to }+10 \text { (full } \\
\text { democracy) }\end{array}$ \\
\hline
\end{tabular}

Notes: UCDP = Uppsala Conflict Data Program (UCDP, 2015); B\&L = Barro and Lee (2013); Maddison = The Maddison-Project (2013); Ross = Ross (2006, 2013) ; Polity IV = Marshall and Jaggers (2002). 
We access the Uppsala Conflict Data Program (UCDP, see UCDP, 2015) to derive yearly country-level information since $1950 .{ }^{6}$ Following the convention in the literature (e.g., Esteban et al., 2012) and the data availability of our educational categories (from Barro and Lee, 2013), we create five year averages and code a country as being in a civil conflict (war) if at least one of the corresponding years has produced $25(1,000)$ or more battle-related deaths. Overall, this gives us 13 periods of observation for 146 countries, producing 1,897 observations. As Table 3 reveals, civil conflict has occurred in approximately 19 percent of our observations, whereas civil war has taken place in 13 percent of the sample (equivalent to 247 of the 1,897 observations). With respect to our control variables, we follow the literature in considering those factors that have continuously been pointed out as robust correlates of civil conflict. These will be discussed shortly.

\subsection{Methodology}

Since the dependent variables are binary indicators, we begin by estimating logit regressions. However, in order to better accommodate country-fixed effects, we then move to a conventional OLS framework. ${ }^{7}$ Specifically, for country $i$ in period $t$, we estimate

$$
\text { Conflict }_{i t}=\alpha_{0}(E d u P)_{i t}+\mathbf{X}_{\mathbf{i t}} \alpha_{1}+\gamma_{i} \alpha_{2}+\epsilon_{i t}
$$

The dependent variable denotes a binary indicator for civil conflict (and later on civil war) that takes on a value of one if the country experiences at least one year with at least 25 battlerelated deaths in the respective five year span. EduP $i t$ represents our index of educational polarization. Further, $\mathbf{X}_{\mathbf{i t}}$ incorporates a set of control variables, capturing important factors that may independently affect the incidence of civil conflict. First, we follow Esteban et al. (2012) by considering the natural logarithm of GDP per capita and population, the volume of oil produced, and the polity 2 variable from the Polity IV dataset, measuring the degree of

\footnotetext{
${ }^{6}$ The UCDP states that data before 1960 can be subject to measurement error. Nevertheless, our findings are virtually identical when excluding data before 1960 .

${ }^{7}$ By design, fixed effects estimations are difficult to conduct and interpret in a logit or probit framework (e.g., see Greene, 2004, or Cameron and Trivedi, 2005), and the literature then usually moves to the more conventional strategy of employing OLS regressions.
} 
democracy. ${ }^{8}$ For a deeper analysis of civil war and its determinants, we refer to Blattman and Miguel (2010). In addition, as our focus lies on education, we control for average years of schooling. This ensures that our results are not driven by the overall level of schooling, but rather the distribution of educational attainment.

$\gamma_{i}$ represents country fixed effects that are intended to control for factors that are timeinvariant or only change very slowly over time. For example, geographical aspects are sometimes discussed as independent drivers of conflict, such as mountainous terrain (e.g., see Fearon and Laitin, 2003, Reynal-Querol and Montalvo, 2005, or Collier et al., 2009). In general, introducing country-fixed effects allows us to exploit within-country variation only, substantially reducing the likelihood of a potential omitted variable bias. Finally, $\epsilon_{i s}$ denotes the usual error term and we cluster error terms at the country level throughout all our estimations.

In extensions, we also consider the influence from other potential determinants, such as the lagged dependent variable, natural resources, ethnic and religious polarization and fractionalization, alternative measures for political institutions (political rights and executive constraints), as well as military capabilities of the respective government. The respective summary statistics are referred to the appendix Table A1. Finally, we also incorporate time trends (global and then country-specific) into our specification.

\section{Main Results}

\subsection{Civil Conflict}

We begin by analyzing civil conflict in Table 4, where column (1) displays results from a univariate regression that only considers $E d u P$ as a regressor to explain the occurrence of a civil conflict in a logit regression framework. Columns (2) to (4) then add further control variables, before switching to an OLS structure in column (5). Column (6) incorporates country-fixed effects.

In column (1), educational polarization emerges as a positive and statistically meaningful

\footnotetext{
${ }^{8}$ Regarding the importance of income levels and population size, we refer to Collier and Hoeffler (1998) and Cotet and Tsui (2013), for example. Oil has been highlighted as a potential driver of civil conflict by Fearon and Laitin (2003), among other scholars (also see Cotet and Tsui, 2013). Democracy, or the absence thereof, has consistently been associated with conflicts, for example by Conconi et al. (2014) or Fearon and Laitin (2003).
} 
Table 4: Results from logit and OLS regressions, estimating the occurrence of civil conflict $(0 / 1)$, indicating at least one year with $25+$ battle-related deaths. All variables constitute 5-year averages and results from logit regressions display marginal effects.

\begin{tabular}{|c|c|c|c|c|c|c|}
\hline & \multicolumn{4}{|c|}{ Logit regressions } & \multicolumn{2}{|c|}{ OLS regressions } \\
\hline & (1) & $(2)$ & (3) & (4) & (5) & $(6)$ \\
\hline \multicolumn{7}{|c|}{ Dependent variable: Civil conflict (25+ deaths) } \\
\hline Educational polarization & $\begin{array}{c}0.320^{* *} \\
(0.155)\end{array}$ & $\begin{array}{c}0.565^{* * *} \\
(0.157)\end{array}$ & $\begin{array}{c}0.654^{* * *} \\
(0.167)\end{array}$ & $\begin{array}{c}0.477^{* * *} \\
(0.178)\end{array}$ & $\begin{array}{l}0.473^{* *} \\
(0.185)\end{array}$ & $\begin{array}{l}0.514^{* *} \\
(0.208)\end{array}$ \\
\hline Years of schooling & & $\begin{array}{c}-0.030^{* * *} \\
(0.008)\end{array}$ & $\begin{array}{l}-0.011 \\
(0.011)\end{array}$ & $\begin{array}{c}-0.033^{* *} \\
(0.013)\end{array}$ & $\begin{array}{c}-0.029^{* * *} \\
(0.011)\end{array}$ & $\begin{array}{c}-0.041^{* * *} \\
(0.015)\end{array}$ \\
\hline $\operatorname{Ln}(\mathrm{GDP} / \mathrm{cap})$ & & & $\begin{array}{c}-0.066^{* *} \\
(0.027)\end{array}$ & $\begin{array}{c}-0.060^{* *} \\
(0.031)\end{array}$ & $\begin{array}{c}-0.069^{* *} \\
(0.028)\end{array}$ & $\begin{array}{c}0.048 \\
(0.038)\end{array}$ \\
\hline $\operatorname{Ln}($ population size) & & & & $\begin{array}{c}0.066^{* * *} \\
(0.020)\end{array}$ & $\begin{array}{c}0.072^{* * *} \\
(0.019)\end{array}$ & $\begin{array}{c}0.157^{* * *} \\
(0.057)\end{array}$ \\
\hline Oil production & & & & $\begin{array}{c}0.003 \\
(0.003)\end{array}$ & $\begin{array}{c}0.003 \\
(0.002)\end{array}$ & $\begin{array}{l}-0.003 \\
(0.004)\end{array}$ \\
\hline Polity & & & & $\begin{array}{c}0.006^{* *} \\
(0.003)\end{array}$ & $\begin{array}{l}0.007^{* *} \\
(0.003)\end{array}$ & $\begin{array}{c}0.005 \\
(0.004)\end{array}$ \\
\hline Country-fixed effects & & & & & & yes \\
\hline \# of countries & 146 & 146 & 138 & 126 & 126 & 126 \\
\hline \# of time periods & 13 & 13 & 13 & 13 & 13 & 13 \\
\hline$N$ & 1,897 & 1,897 & 1,535 & 1,240 & 1,240 & 1,240 \\
\hline Adjusted $R^{2}$ & & & & & 0.161 & 0.416 \\
\hline
\end{tabular}

Notes: Standard errors clustered on the country level are displayed in parentheses. ${ }^{*} p<0.10,{ }^{* *} p<0.05,{ }^{* * *}$ $p<0.01$. 
correlate of the likelihood that a country experiences a civil conflict. In terms of magnitude, a one standard deviation increase of $E d u P$ (equivalent to 0.09 ) would be associated with a 3.2 percent increase in the likelihood to experience civil conflict. As control variables are included, this coefficient strengthens, both in terms of statistical precision and magnitude. Other insights from these first estimations reveal that more schooling and higher income levels relate to a smaller likelihood of conflict. These results are consistent with our intuition and previous findings in the associated literature. Interestingly, democracy is positively associated with the chances of conflict, although we will shortly see that once country-fixed effects are accounted for no statistically meaningful relationship prevails.

Column (5) replicates the logit regression considered in column (4) in an OLS structure and we can see that the derived coefficients only change marginally. It is interesting to see that the inclusion of country-fixed effects in column (6) actually strengthens the implied relationship between $E d u P$ and the chances of a conflict. This provides additional confidence that results from pooled cross-sectional regressions are not spurious and country-specific characteristics are unlikely to drive this relationship. A quantitative interpretation of the coefficient related to $E d u P$ in the most complete estimation indicates that a one standard deviation increase of $E d u P$ corresponds to a 4.6 percentage point increase in the likelihood of experiencing a civil conflict.

\subsection{Civil War}

With these results in mind, we now move to analyzing the occurrence of civil war in Table 5. We follow the same sequence of regressions and find very similar results to Table 4 . When we consider $E d u P$ as the only regressor, a jump from no polarization $(E P=0)$ to complete polarization $(E P=1)$ would raise the chances of a civil war by as much as 29 percentage points.

As with civil conflict, this relationship is confirmed and further gains statistical importance when adding the conventional control variables. Including country-fixed effects re-enforces this result, indicating that, if anything, unobservable factors on the country level may introduce a downward bias in a pooled analysis of the link between $E d u P$ and civil war. In our most complete estimation, a one standard deviation increase in $E d u P$ is suggested to raise the chances of a 
Table 5: Results from logit and OLS regressions, estimating the occurrence of civil war (0/1), indicating at least one year with 1,000+ battle-related deaths. All variables constitute 5 -year averages and results from logit regressions display marginal effects.

\begin{tabular}{|c|c|c|c|c|c|c|}
\hline & \multicolumn{4}{|c|}{ Logit regressions } & \multicolumn{2}{|c|}{ OLS regressions } \\
\hline & $(1)$ & $(2)$ & $(3)$ & (4) & (5) & $(6)$ \\
\hline \multicolumn{7}{|c|}{ Dependent variable: Civil war $(1,000+$ deaths $)$} \\
\hline Educational polarization & $\begin{array}{c}0.290^{* *} \\
(0.139)\end{array}$ & $\begin{array}{c}0.418^{* * *} \\
(0.136)\end{array}$ & $\begin{array}{c}0.509^{* * *} \\
(0.150)\end{array}$ & $\begin{array}{c}0.334^{* *} \\
(0.158)\end{array}$ & $\begin{array}{c}0.403^{* *} \\
(0.166)\end{array}$ & $\begin{array}{l}0.427^{* *} \\
(0.165)\end{array}$ \\
\hline Years of schooling & & $\begin{array}{c}-0.017^{* *} \\
(0.007)\end{array}$ & $\begin{array}{c}0.002 \\
(0.010)\end{array}$ & $\begin{array}{l}-0.011 \\
(0.012)\end{array}$ & $\begin{array}{l}-0.010 \\
(0.010)\end{array}$ & $\begin{array}{l}-0.012 \\
(0.011)\end{array}$ \\
\hline $\operatorname{Ln}(\mathrm{GDP} / \mathrm{cap})$ & & & $\begin{array}{c}-0.066^{* *} \\
(0.026)\end{array}$ & $\begin{array}{c}-0.060^{* *} \\
(0.027)\end{array}$ & $\begin{array}{c}-0.067^{* *} \\
(0.026)\end{array}$ & $\begin{array}{c}0.008 \\
(0.032)\end{array}$ \\
\hline $\operatorname{Ln}($ population size) & & & & $\begin{array}{c}0.055^{* * *} \\
(0.019)\end{array}$ & $\begin{array}{c}0.064^{* * *} \\
(0.019)\end{array}$ & $\begin{array}{l}0.124^{* *} \\
(0.052)\end{array}$ \\
\hline Oil production & & & & $\begin{array}{c}0.002 \\
(0.002)\end{array}$ & $\begin{array}{c}0.002 \\
(0.002)\end{array}$ & $\begin{array}{l}-0.003 \\
(0.003)\end{array}$ \\
\hline Polity & & & & $\begin{array}{c}0.002 \\
(0.003)\end{array}$ & $\begin{array}{c}0.003 \\
(0.003)\end{array}$ & $\begin{array}{c}0.001 \\
(0.003)\end{array}$ \\
\hline Country-fixed effects & & & & & yes & yes \\
\hline \# of countries & 146 & 146 & 138 & 126 & 126 & 126 \\
\hline \# of time periods & 13 & 13 & 13 & 13 & 13 & 13 \\
\hline$N$ & 1,897 & 1,897 & 1,535 & 1,240 & 1,240 & 1,240 \\
\hline Adjusted $R^{2}$ & & & & & 0.121 & 0.474 \\
\hline
\end{tabular}

Notes: Standard errors clustered on the country level are displayed in parentheses. ${ }^{*} p<0.10,{ }^{* *} p<0.05,{ }^{* * *}$ $p<0.01$. 
civil war by 3.8 percentage points. This is a substantial change, given that we witness civil war in "only" ten percent of our sample observations.

We now move to a series of robustness checks, departing from the most complete estimation for civil conflict and civil war, displayed in column (6) of Tables 4 and 5.

\section{Robustness Checks}

\subsection{Dynamics and Resource Rents}

Our first robustness check, displayed in columns (1) and (4) of Table 6, incorporates the lagged dependent variable. Naturally, the best predictor of conflict today may be the occurrence of conflict yesterday and civil unrest tends to be path-dependent (see Miguel and Satyanath, 2011, Esteban et al., 2012, Nunn and Qian, 2012, 2014, or Hull and Imai, 2013). Indeed, the lagged dependent variable emerges as a strong predictor for conflict and civil war. However, our main result associated with the role of $E d u P$ remains largely unaffected.

Following Bewley (1979), we can calculate the long-run link between EduP and the chances of

civil conflict in this dynamic estimation: $\frac{\beta_{E d u P}}{1-\beta_{\text {lagged conflict }}}=0.543$. A quantitative interpretation of this coefficient indicates that a one standard deviation increase of $E d u P$ corresponds to a 4.9 percentage point increase in the likelihood of experiencing a civil conflict. The corresponding magnitude for civil war, analyzed in column (4), takes on a value of 5.8 percentage points.

Further, columns (2) and (3), as well as (5) and (6), consider the role of natural resource rents and in particular oil rents. Although our baseline regression already controls for oil production, we want to ensure that oil, a commodity that has consistently been linked to civil unrest, is not driving our findings related to $E d u P$. However, once we include the respective variables derived from the World Development Indicators, the benchmark result prevails and EduP remains a powerful predictor of civil unrest, both in terms of statistical and economic relevance.

\subsection{Ethnic Polarization and Fractionalization}

As our focus lies on the polarization of society along the line of education levels, it is important to test whether our results can be explained by other forms of polarization or fractionalization. Thus, Table 7 replicates our benchmark estimation, including ethnic polarization and fraction- 
Table 6: Results from logit and OLS regressions, testing for the influence of past conflicts, natural resource rents, and oil rents. All variables constitute 5-year averages.

\begin{tabular}{|c|c|c|c|c|c|c|}
\hline \multirow[t]{2}{*}{ Dependent variable: } & \multicolumn{3}{|c|}{$\begin{array}{l}\text { Civil conflict } \\
(25+\text { deaths }) \\
\end{array}$} & \multicolumn{3}{|c|}{$\begin{array}{c}\text { Civil war } \\
(1,000+\text { deaths })\end{array}$} \\
\hline & $(1)$ & $(2)$ & (3) & $(4)$ & $(5)$ & $(6)$ \\
\hline Educational polarization & $\begin{array}{l}0.396^{* *} \\
(0.159)\end{array}$ & $\begin{array}{l}0.635^{* *} \\
(0.258)\end{array}$ & $\begin{array}{l}0.628^{* *} \\
(0.255)\end{array}$ & $\begin{array}{l}0.468^{* *} \\
(0.186)\end{array}$ & $\begin{array}{c}0.617^{* * *} \\
(0.215)\end{array}$ & $\begin{array}{c}0.621^{* * *} \\
(0.213)\end{array}$ \\
\hline Lagged dependent variable & $\begin{array}{c}0.271^{* * *} \\
(0.042)\end{array}$ & & & $\begin{array}{c}0.241^{* * *} \\
(0.046)\end{array}$ & & \\
\hline Natural resource rents & & $\begin{array}{l}0.005^{* *} \\
(0.002)\end{array}$ & & & $\begin{array}{c}0.006^{* * *} \\
(0.002)\end{array}$ & \\
\hline Oil rents & & & $\begin{array}{c}0.003 \\
(0.002)\end{array}$ & & & $\begin{array}{l}0.003^{*} \\
(0.002)\end{array}$ \\
\hline Control variables ${ }^{a}$ & yes & yes & yes & yes & yes & yes \\
\hline Country-fixed effects & yes & yes & yes & yes & yes & yes \\
\hline \# of countries & 126 & 124 & 125 & 126 & 124 & 125 \\
\hline \# of time periods & 12 & 9 & 9 & 12 & 9 & 9 \\
\hline$N$ & 1,211 & 932 & 951 & 1,211 & 932 & 951 \\
\hline Adjusted $R^{2}$ & 0.467 & 0.453 & 0.461 & 0.448 & 0.531 & 0.538 \\
\hline
\end{tabular}

Notes: Standard errors clustered on the country level are displayed in parentheses. ${ }^{*} p<0.10,{ }^{* *} p<0.05,{ }^{* * *}$ $p<0.01$. ${ }^{a}$ Includes schooling, GDP/capita, population size, oil production, and the Polity IV index of democracy (variable polity 2 ). 
alization values. ${ }^{9}$ Note that, since these values are only available once for every country (from Montalvo and Reynal-Querol, 2005, or previously Alesina et al., 2003), we are forced to exclude country-fixed effects. However, since the results from a pooled regression in Tables 4 and 5 are, if anything, weaker than those from including fixed effects, we are confident that a pooled regression is able to reveal whether ethnic shares are driving our findings.

Table 7: Results from logit and OLS regressions, considering ethnic polarization and fractionalization. All regressions estimate the occurrence of civil conflict and civil war (0/1), indicating at least one year with $25+$ or $1,000+$ battle-related deaths, respectively. All variables constitute 5-year averages.

\begin{tabular}{|c|c|c|c|c|c|c|}
\hline \multirow[t]{2}{*}{ Dependent variable: } & \multicolumn{3}{|c|}{ Civil conflict $(25+$ deaths $)$} & \multicolumn{3}{|c|}{ Civil war $(1,000+$ deaths $)$} \\
\hline & (1) & $(2)$ & (3) & $(4)$ & (5) & (6) \\
\hline Educational polarization & $\begin{array}{l}0.473^{* *} \\
(0.228)\end{array}$ & $\begin{array}{l}0.476^{* *} \\
(0.232)\end{array}$ & $\begin{array}{l}0.472^{* *} \\
(0.227)\end{array}$ & $\begin{array}{l}0.327^{*} \\
(0.176)\end{array}$ & $\begin{array}{l}0.338^{*} \\
(0.177)\end{array}$ & $\begin{array}{l}0.321^{*} \\
(0.176)\end{array}$ \\
\hline Ethnic polarization & $\begin{array}{c}-0.011 \\
(0.108)\end{array}$ & $\begin{array}{l}-0.036 \\
(0.178)\end{array}$ & & $\begin{array}{l}-0.059 \\
(0.101)\end{array}$ & $\begin{array}{l}-0.161 \\
(0.164)\end{array}$ & \\
\hline Ethnic fractionalization & & $\begin{array}{c}0.036 \\
(0.180)\end{array}$ & & & $\begin{array}{c}0.145 \\
(0.172)\end{array}$ & \\
\hline Control variables $^{a}$ & yes & yes & yes & yes & yes & yes \\
\hline \# of countries & 73 & 73 & 73 & 73 & 73 & 73 \\
\hline \# of time periods & 13 & 13 & 13 & 13 & 13 & 13 \\
\hline$N$ & 732 & 732 & 732 & 732 & 732 & 732 \\
\hline Adjusted $R^{2}$ & 0.158 & 0.157 & 0.159 & 0.112 & 0.117 & 0.111 \\
\hline
\end{tabular}

Notes: Standard errors clustered on the country level are displayed in parentheses. ${ }^{*} p<0.10,{ }^{* *} p<0.05,{ }^{* * *}$ $p<0.01$. ${ }^{a}$ Includes schooling, GDP/capita, population size, oil production, and the Polity IV index of democracy (variable polity2).

In Table 7, we begin with analyzing civil conflict in columns (1) to (3). We subsequently include ethnic polarization and fractionalization, before re-estimating our benchmark regression with only those observations for which we have data on ethnic shares. Note that our sample

\footnotetext{
${ }^{9}$ Ethnic polarization has received a lot of attention in the literature on civil war determinants. Examples can be found by Bhavnani and Miodownik (2009), Klasnja and Novta (2014), Reynal-Querol and Montalvo (2005), Montalvo and Reynal-Querol (2010).
} 
size decreases by over 40 percent from 1,240 to 732 , due to the availability of information on ethnicity. Columns (4) to (6) then follow the same sequence of regressions for civil war.

The results produce at least two insights. First, we find no evidence that ethnic polarization or fractionalization are driving the results related to EduP. Second, and potentially interesting outside our immediate research question here, ethnic shares do not appear as meaningful predictors of civil conflict or civil war per se. This stands in contrast to previous findings by Collier and Hoeffler (1998, 2004), Fearon and Laitin (2003), Reynal-Querol and Montalvo (2005), Esteban et al. (2012), or Cotet and Tsui (2013).

\subsection{Religious Polarization and Fractionalization}

Beyond ethnic shares, it is possible that the religious denomination of the populace is able to explain our result pertaining to $E d u P$. For example, particular religious denominations may systematically view education differently than others or EduP may simply be correlated to religious shares in a society, which may introduce an omitted variable bias into our benchmark estimation. ${ }^{10}$

Table 8 first considers the shares of Muslims, Catholics, and Protestants in a society and then also, in the spirit of our analysis, turns to religious polarization and fractionalization. As with ethnic shares, we only have one data point per country and therefore omit country-fixed effects. Here again, the positive association between EduP and civil unrest prevails. Independently, religious shares do not seem to be systematically associated with civil conflict or civil war once all control variables are taken into account.

\subsection{Political Institutions and Military Power}

Our penultimate series of robustness checks considers the political institutions of the respective countries. In our baseline estimation, we employ the polity 2 variable from the Polity IV dataset, but other studies have highlighted varying aspects of political institutions that could be important when explaining conflicts. For example, Collier and Hoeffler (2004) advocate the role of political rights, whereas Conconi et al. (2014) discuss electoral accountability. ${ }^{11}$

\footnotetext{
${ }^{10}$ For the link between various facets of religion and conflict, we refer to Basedau et al. (2016).

${ }^{11}$ The paper by Conconi et al. (2014) focuses on term limits, but since this variable is largely time-invariant within a country, our fixed effects estimations control for such characteristics.
} 
Table 8: Results from logit and OLS regressions, considering religious population shares, religious polarization, and religious fractionalization. All regressions estimate the occurrence of civil conflict and civil war $(0 / 1)$, indicating at least one year with $25+$ or $1,000+$ battle-related deaths, respectively. All variables constitute 5-year averages.

\begin{tabular}{|c|c|c|c|c|c|c|}
\hline \multirow[t]{2}{*}{ Dependent variable: } & \multicolumn{3}{|c|}{ Civil conflict $(25+$ deaths $)$} & \multicolumn{3}{|c|}{ Civil war (1,000+ deaths) } \\
\hline & (1) & $(2)$ & $(3)$ & $(4)$ & $(5)$ & $(6)$ \\
\hline Educational polarization & $\begin{array}{c}0.630^{* * *} \\
(0.223)\end{array}$ & $\begin{array}{c}0.466^{* *} \\
(0.224)\end{array}$ & $\begin{array}{l}0.464^{* *} \\
(0.223)\end{array}$ & $\begin{array}{c}0.646^{* * *} \\
(0.214)\end{array}$ & $\begin{array}{l}0.315^{*} \\
(0.172)\end{array}$ & $\begin{array}{l}0.312^{*} \\
(0.169)\end{array}$ \\
\hline$\%$ Muslims & $\begin{array}{c}-0.001 \\
(0.001)\end{array}$ & & & $\begin{array}{l}-0.001 \\
(0.001)\end{array}$ & & \\
\hline \% Catholic & $\begin{array}{l}-0.002 \\
(0.001)\end{array}$ & & & $\begin{array}{l}-0.001 \\
(0.002)\end{array}$ & & \\
\hline$\%$ Protestant & $\begin{array}{l}-0.001 \\
(0.002)\end{array}$ & & & $\begin{array}{l}-0.000 \\
(0.002)\end{array}$ & & \\
\hline Religious polarization & & $\begin{array}{c}-0.031 \\
(0.082)\end{array}$ & & & $\begin{array}{l}-0.028 \\
(0.077)\end{array}$ & \\
\hline Religious fractionalization & & & $\begin{array}{l}-0.044 \\
(0.124)\end{array}$ & & & $\begin{array}{l}-0.054 \\
(0.113)\end{array}$ \\
\hline Control variables ${ }^{a}$ & yes & yes & yes & yes & yes & yes \\
\hline \# of countries & 74 & 73 & 73 & 74 & 73 & 73 \\
\hline \# of time periods & 11 & 13 & 13 & 11 & 13 & 13 \\
\hline$N$ & 711 & 732 & 732 & 711 & 732 & 732 \\
\hline Adjusted $R^{2}$ & 0.201 & 0.158 & 0.158 & 0.135 & 0.110 & 0.111 \\
\hline
\end{tabular}

Notes: Standard errors clustered on the country level are displayed in parentheses. ${ }^{*} p<0.10,{ }^{* *} p<0.05,{ }^{* * *}$ $p<0.01$. ${ }^{a}$ Includes schooling, GDP/capita, population size, oil production, and the Polity IV index of democracy (variable polity2). 
Table 9: Results from logit and OLS regressions, considering alternative measures for political institutions. All regressions estimate the occurrence of civil conflict and civil war $(0 / 1)$, indicating at least one year with $25+$ or $1,000+$ battle-related deaths, respectively. All variables constitute 5-year averages.

\begin{tabular}{|c|c|c|c|c|c|c|}
\hline \multirow[t]{2}{*}{ Dependent variable: } & \multicolumn{3}{|c|}{ Civil conflict $(25+$ deaths $)$} & \multicolumn{3}{|c|}{ Civil war $(1,000+$ deaths $)$} \\
\hline & (1) & $(2)$ & $(3)$ & (4) & (5) & (6) \\
\hline Educational polarization & $\begin{array}{l}0.609^{* *} \\
(0.236)\end{array}$ & $\begin{array}{c}0.575^{* * *} \\
(0.211)\end{array}$ & $\begin{array}{l}0.553^{* *} \\
(0.221)\end{array}$ & $\begin{array}{c}0.579^{* * *} \\
(0.192)\end{array}$ & $\begin{array}{c}0.474^{* * *} \\
(0.166)\end{array}$ & $\begin{array}{l}0.409^{* *} \\
(0.166)\end{array}$ \\
\hline Political rights & $\begin{array}{c}0.001 \\
(0.012)\end{array}$ & & & $\begin{array}{c}0.011 \\
(0.010)\end{array}$ & & \\
\hline Executive constraints & & $\begin{array}{c}-0.001 \\
(0.013)\end{array}$ & & & $\begin{array}{l}-0.014 \\
(0.009)\end{array}$ & \\
\hline National capability score & & & $\begin{array}{c}3.153 \\
(4.295)\end{array}$ & & & $\begin{array}{l}-0.309 \\
(1.581)\end{array}$ \\
\hline Country-fixed effects & yes & yes & yes & yes & yes & yes \\
\hline Control variables ${ }^{a}$ & yes & yes & yes & yes & yes & yes \\
\hline \# of countries & 125 & 125 & 123 & 125 & 125 & 123 \\
\hline \# of time periods & 9 & 11 & 10 & 9 & 11 & 10 \\
\hline$N$ & 1,012 & 1,196 & 1,070 & 1,012 & 1,196 & 1,070 \\
\hline Adjusted $R^{2}$ & 0.480 & 0.435 & 0.423 & 0.551 & 0.506 & 0.489 \\
\hline
\end{tabular}

Notes: Standard errors clustered on the country level are displayed in parentheses. ${ }^{*} p<0.10,{ }^{* *} p<0.05,{ }^{* * *}$ $p<0.01$. ${ }^{a}$ Includes schooling, GDP/capita, population size, oil production, and the Polity IV index of democracy (variable polity2). Columns (1), (2), (4), and (5) exclude the Polity index. 
Thus, columns (1) and (2) of Table 9, as well as (4) and (5), incorporate political rights and executive constraints. Most importantly, the result pertaining to $E d u P$ remains robust. Further, we find no evidence that political rights or better executive constraints are systematically associated with a lower likelihood of civil unrest, at least once country-fixed effects are considered.

We then also consider a military aspect of ruling governments by incorporating the CINC score that measures the military capability of the respective country. Intuitively, a stronger military may deter a violent rebellion, everything else equal, and we want to ensure that such dynamics are not confounding our findings. However, that does not seem to be the case, as revealed by the results displayed in columns (3) and (6) of Table 9.

\subsection{Global and Country-Specific Time Trends}

For our final robustness check, we consider time trends, first on a global level and then specific to every individual country. For instance, over time, both $E d u P$ and the likelihood of civil unrest may have changed simultaneously worldwide, potentially driven by the end of the Cold War or other remarkable historical events. If this were the case, then our benchmark findings could be spurious. Similarly, a given country could have taken distinct developments over time that may correlate with both $E d u P$ and the dependent variable.

To check whether such dynamics are relevant, Table 10 first includes global time trends in columns (1) and (3) and then considers country-specific time trends in columns (2) and (4). It is interesting to see that our findings remain virtually unchanged in terms of their economic importance, indicating the relationship between $E d u P$ and civil unrest to be time-independent. Note that we only have 13 time periods available overall, which makes these regressions relatively tight in an econometric sense, leaving less statistical variation to be explained by the respective covariates. It is remarkable that, even in such a regression format, $E d u P$ remains a statistically powerful predictor, further lending support to a systematic connection between $E d u P$ and civil unrest. 
Table 10: Results from logit and OLS regressions, incorporating general and country-specific time trends. All regressions estimate the occurrence of civil conflict and civil war $(0 / 1)$, indicating at least one year with $25+$ or $1,000+$ battle-related deaths, respectively. All variables constitute 5-year averages.

\begin{tabular}{|c|c|c|c|c|}
\hline \multirow[t]{2}{*}{ Dependent variable: } & \multicolumn{2}{|c|}{ Civil conflict $(25+$ deaths $)$} & \multicolumn{2}{|c|}{ Civil war $(1,000+$ deaths $)$} \\
\hline & (1) & $(2)$ & $(3)$ & (4) \\
\hline Educational polarization & $\begin{array}{c}0.482^{* *} \\
(0.213)\end{array}$ & $\begin{array}{l}0.430^{*} \\
(0.221)\end{array}$ & $\begin{array}{c}0.396^{* *} \\
(0.172)\end{array}$ & $\begin{array}{l}0.454^{* *} \\
(0.204)\end{array}$ \\
\hline Time trend & $\begin{array}{c}0.002 \\
(0.002)\end{array}$ & $\begin{array}{c}0.022^{* * *} \\
(0.004)\end{array}$ & $\begin{array}{c}0.000 \\
(0.002)\end{array}$ & $\begin{array}{c}0.017^{* * *} \\
(0.004)\end{array}$ \\
\hline Country-specific time trends & & yes & & yes \\
\hline Control variables ${ }^{a}$ & yes & yes & yes & yes \\
\hline Country-fixed effects & yes & yes & yes & yes \\
\hline \# of countries & 126 & 126 & 126 & 126 \\
\hline \# of time periods & 13 & 13 & 13 & 13 \\
\hline$N$ & 1,240 & 1,240 & 1,240 & 1,240 \\
\hline Adjusted $R^{2}$ & 0.416 & 0.501 & 0.475 & 0.559 \\
\hline
\end{tabular}

Notes: Standard errors clustered on the country level are displayed in parentheses. ${ }^{*} p<0.10,{ }^{* *} p<0.05,{ }^{* * *}$ $p<0.01$. ${ }^{a}$ Includes schooling, GDP/capita, population size, oil production, and the Polity IV index of democracy (variable polity 2 ). 


\section{Conclusions}

This paper argues that countries with a large degree of educational polarization $(E d u P)$ are more likely to experience civil conflict and civil war. Although previous research has highlighted a generally polarized society to be more likely to experience violent conflict on a domestic level, to our knowledge we are the first to highlight educational polarization. Intuitively, highly educated citizens are likely to differ fundamentally from uneducated citizens in their political preferences and beliefs, and these educational cleavages can raising the chance of civil conflict, everything else equal.

We first calculate a novel measure of $E d u P$ and then apply this index to a dataset of 146 countries from 1950 to 2010. Employing five-year averages (i.e., 1950 - 1954,..., 2010 - 2014), we find a strong link between $E d u P$ and the likelihood of a country experiencing civil conflict or civil war. This relationship is robust to including the conventional control variables, country-fixed effects, and country-specific time trends.

In terms of magnitude, a one standard deviation increase of $E d u P$ is associated with a 4.6 percentage point rise in the chances of civil conflict and a 3.8 percentage point rise in the likelihood of civil war. This suggests that, in order to diminish the odds of large civil unrest, policymakers should keep an eye on the polarization of education levels in society. The larger the groups at the extreme ends of no schooling and university education, the more likely we are to see large-scale civil unrest, everything else equal. 


\section{References}

Alesina, A., Devleeschauwer, A., Easterly, W., Kurlat, S., and Wacziarg, R. (2003). Fractionalization. Journal of Economic Growth, 8(2):155-194.

Apouey, B. (2007). Measuring health polarization with self-assessed health data. Health Economics, 16(9):875-894.

Barro, R. J. and Lee, J. W. (2013). A new data set of educational attainment in the world, 1950-2010. Journal of Development Economics, 104:184-198.

Basedau, M., Pfeiffer, B., and Vüllers, J. (2016). Bad religion? Religion, collective action, and the onset of armed conflict in developing countries. Journal of Conflict Resolution, 60(2):226255.

BBC News (2016). EU referendum: The result in maps and charts. http://www.bbc.com/ news/uk-politics-36616028. [Online; accessed 05-August-2016].

Bewley, R. A. (1979). The direct estimation of the equilibrium response in a linear dynamic model. Economics Letters, 3(4):357-361.

Bhavnani, R. and Miodownik, D. (2009). Ethnic polarization, ethnic salience, and civil war. Journal of Conflict Resolution, 53(1):30-49.

Blattman, C. and Miguel, E. (2010). Civil war. Journal of Economic Literature, 48(1):3-57.

Bosker, M. and de Ree, J. (2014). Ethnicity and the spread of civil war. Journal of Development Economics, 108:206-221.

Cameron, A. C. and Trivedi, P. K. (2005). Microeconometrics: methods and applications. Cambridge university press.

Castelló, A. and Doménech, R. (2002). Human capital inequality and economic growth: Some new evidence. The Economic Journal, 112(478):C187-C200.

Collier, P. and Hoeffler, A. (1998). On economic causes of civil war. Oxford Economic Papers, 50(4):563-573. 
Collier, P. and Hoeffler, A. (2004). Greed and grievance in civil war. Oxford Economic Papers, $56(4): 563-595$.

Collier, P., Hoeffler, A., and Rohner, D. (2009). Beyond greed and grievance: Feasibility and civil war. Oxford Economic Papers, 61(1):1-27.

Conconi, P., Sahuguet, N., and Zanardi, M. (2014). Democratic peace and electoral accountability. Journal of the European Economic Association, 12(4):997-1028.

Cotet, A. M. and Tsui, K. K. (2013). Oil and conflict: What does the cross country evidence really show? American Economic Journal: Macroeconomics, 5(1):49-80.

Esteban, J., Mayoral, L., and Ray, D. (2012). Ethnicity and conflict: An empirical study. The American Economic Review, 102(4):1310-42.

Esteban, J. and Ray, D. (1999). Conflict and distribution. Journal of Economic Theory, $87(2): 379-415$.

Esteban, J. and Ray, D. (2008). On the salience of ethnic conflict. The American Economic Review, 98(5):2185-2202.

Esteban, J. and Ray, D. (2011). Linking conflict to inequality and polarization. The American Economic Review, 101(4):1345-1374.

Esteban, J.-M. and Ray, D. (1994). On the measurement of polarization. Econometrica, $62(4): 819-851$.

Fearon, J. D. and Laitin, D. D. (2003). Ethnicity, insurgency, and civil war. American Political Science Review, 97(01):75-90.

Ferreira, F. H. and Gignoux, J. (2014). The measurement of educational inequality: Achievement and opportunity. The World Bank Economic Review, 28(2):210-246.

FreedomHouse (2014). All countries score. http\{www.freedomhouse.org\}.

Greene, W. (2004). The behaviour of the maximum likelihood estimator of limited dependent variable models in the presence of fixed effects. The Econometrics Journal, 7(1):98-119. 
Group, W. B. (2012). World Development Indicators 2012. World Bank Publications.

Hull, P. and Imai, M. (2013). Economic shocks and civil conflict: Evidence from foreign interest rate movements. Journal of Development Economics, 103:77-89.

Kirk, A. and Scott, P. (2016). US election: How age, race and education are deciding factors in the race for President. The Telegraph, November 7, 2016.

Klasnja, M. and Novta, N. (2014). Segregation, polarization, and ethnic conflict. Journal of Conflict Resolution, pages 1-29.

Lanyon, C. (2016). Hundreds of Hate Crimes Have Been Reported Since the Election. New York Magazine, November 13, 2016. [Online; accessed 12/12/2016].

Marshall, M. G. and Jaggers, K. (2002). Polity IV project: Political regime characteristics and transitions, 1800-2002.

Miguel, E. and Satyanath, S. (2011). Re-examining economic shocks and civil conflict. American Economic Journal: Applied Economics, 3(4):228-232.

Montalvo, J. G. and Reynal-Querol, M. (2005). Ethnic diversity and economic development. Journal of Development Economics, 76(2):293-323.

Montalvo, J. G. and Reynal-Querol, M. (2010). Ethnic polarization and the duration of civil wars. Economics of Governance, 11(2):123-143.

Morrisson, C. and Murtin, F. (2013). The Kuznets curve of human capital inequality: 1870-2010. The Journal of Economic Inequality, 11(3):283-301.

Nagesh, A. (2016). Hate crimes soar across the US after Donald Trump elected. Metro.co.uk, November 12, 2016. [Online; accessed 12/12/2016].

Nunn, N. and Qian, N. (2012). Aiding conflict: The impact of US food aid on civil war. Technical report, National Bureau of Economic Research.

Nunn, N. and Qian, N. (2014). US food aid and civil conflict. The American Economic Review, 104(6):1630-1666. 
Okeowo, A. (2016). Hate on the Rise After Trump's Election. The New Yorker, November 17, 2016. [Online; accessed 12/12/2016].

Østby, G. (2008). Polarization, horizontal inequalities and violent civil conflict. Journal of Peace Research, 45(2):143-162.

Peters, J. W., Thee-Brenan, M., and Sussman, D. (2016). Election exit polls reveal a starkly divided nation. The New York Times, November 8, 2016.

Puglise, N. (2016). Exit polls and election results - what we learned. The Guardian, November $12,2016$.

Reynal-Querol, M. and Montalvo, J. G. (2005). Ethnic polarization, potential conflict and civil war. The American Economic Review, 95(3):796-816.

Ross, M. (2006). A closer look at oil, diamonds, and civil war. Annu. Rev. Polit. Sci., 9:265-300.

Ross, M. L. (2013). Oil and gas data, 1932-2011.

Singer, J. David, S. B. and Stuckey, J. (1972). Capability Distribution, Uncertainty, and Major Power War, 1820-1965. Peace, War, and Numbers, Beverly Hills: Sage, 19-48.

Solt, F. (2009). Standardizing the World Income Inequality Database. Social Science Quarterly, $90(2): 231-242$.

Solt, F. (2016). The standardized world income inequality database. Social Science Quarterly.

Stewart, F. (2005). Horizontal inequalities: A neglected dimension of development. In WIDER Perspectives on Global Development, pages 101-135. Springer.

Stewart, F. et al. (2002). Horizontal inequalities: A neglected dimension of development, volume 5. Wider.

Teorell, J., Samanni, M., Holmberg, S., and Rothstein, B. (2011). The quality of government basic dataset made from the QoG standard dataset version 6apr11. The Quality of Government Institute, University of Gothenburg. 
The Maddison-Project (2013). The Maddison-project database, available under http://www . ggdc.net/maddison/maddison-project/home.htm.

The Telegraph (2016). EU referendum: How the results compare to the UK's educated, old and immigrant populations. http://www.telegraph.co.uk/news/2016/06/24/ eu-referendum-how-the-results-compare-to-the-uks-educated-old-an/. [Online; accessed 05-August-2016].

Thomas, V., Wang, Y., and Fan, X. (2001). Measuring education inequality: Gini coefficients of education, volume 2525. World Bank Publications.

UCDP (2015). UCDP battle-related deaths dataset v.5-2015, Uppsala Conflict Data Program. www.ucdp.uu.se, Uppsala University. 


\section{Appendix}

Table A1: Summary statistics of additional variables.

\begin{tabular}{|c|c|c|c|c|c|}
\hline Variable & $\begin{array}{c}\text { Mean } \\
\text { (Std. Dev.) }\end{array}$ & $\begin{array}{l}\text { Min. } \\
\text { (Max.) }\end{array}$ & $\mathrm{N}$ & Source $^{a}$ & Description (if necessary) \\
\hline Political stability & $\begin{array}{l}-0.11 \\
(0.96)\end{array}$ & $\begin{array}{l}-2.91 \\
(1.64)\end{array}$ & 575 & WB & $\begin{array}{l}\text { Political Stability and absence of } \\
\text { violence/terrorism }\end{array}$ \\
\hline $\begin{array}{l}\text { Natural resource } \\
\text { rents }\end{array}$ & $\begin{array}{c}9.77 \\
(13.42)\end{array}$ & $\begin{array}{c}0 \\
(75.09)\end{array}$ & 1,114 & WB & $\begin{array}{l}\text { Natural resource rents in } \\
\text { percentage of GDP }\end{array}$ \\
\hline Oil rents & $\begin{array}{c}4.75 \\
(11.30)\end{array}$ & $\begin{array}{c}0 \\
(68.85)\end{array}$ & 1,158 & WB & Oil rents in percentage of GDP \\
\hline Ethnic polarization & $\begin{array}{c}0.5 \\
(0.26)\end{array}$ & $\begin{array}{c}0.02 \\
(0.96)\end{array}$ & 1,130 & $\mathrm{M} \& \mathrm{R}-\mathrm{Q}$ & Ethnic polarization index \\
\hline $\begin{array}{l}\text { Ethnic } \\
\text { fractionalization }\end{array}$ & $\begin{array}{c}0.43 \\
(0.29)\end{array}$ & $\begin{array}{c}0.01 \\
(0.96)\end{array}$ & 1,130 & $\mathrm{M} \& \mathrm{R}-\mathrm{Q}$ & Ethnic fractionalization index \\
\hline$\%$ Muslims & $\begin{array}{c}24.8 \\
(36.57)\end{array}$ & $\begin{array}{c}0 \\
(99.40)\end{array}$ & 968 & QoG & Share of Muslims in society \\
\hline$\%$ Catholics & $\begin{array}{c}33.39 \\
(37.24)\end{array}$ & $\begin{array}{c}0 \\
(97.30)\end{array}$ & 968 & QoG & Share of Catholics in society \\
\hline$\%$ Protestants & $\begin{array}{c}12.21 \\
(21.81)\end{array}$ & $\begin{array}{c}0 \\
(97.80)\end{array}$ & 968 & QoG & Share of Protestants in society \\
\hline $\begin{array}{l}\text { Religious } \\
\text { polarization }\end{array}$ & $\begin{array}{c}0.49 \\
(0.35)\end{array}$ & $\begin{array}{c}0 \\
(0.98)\end{array}$ & 1,130 & $\mathrm{M} \& \mathrm{R}-\mathrm{Q}$ & Religious polarization index \\
\hline $\begin{array}{l}\text { Religious } \\
\text { fractionalization }\end{array}$ & $\begin{array}{c}0.31 \\
(0.24)\end{array}$ & $\begin{array}{c}0 \\
(0.78)\end{array}$ & 1,130 & $\mathrm{M} \& \mathrm{R}-\mathrm{Q}$ & Religious fractionalization index \\
\hline Gini (post-tax & 36.86 & 16.63 & 521 & Solt & $\begin{array}{l}\text { Gini after taxation and transfer } \\
\text { payments }\end{array}$ \\
\hline \& post-transfer) & $(9.45)$ & $(63.90)$ & & & \\
\hline Gini (pre-tax & 45.27 & 26.14 & 521 & Solt & $\begin{array}{l}\text { Gini before taxation and transfer } \\
\text { payments }\end{array}$ \\
\hline \& pre-transfer) & $(7.72)$ & $(73.42)$ & & & \\
\hline Political rights & $\begin{array}{l}3.73 \\
(2.16)\end{array}$ & $\begin{array}{c}1 \\
(7)\end{array}$ & 1,191 & $\mathrm{FH}$ & $\begin{array}{l}\text { Political rights, decreasing } \\
\text { from } 1 \text { to } 7\end{array}$ \\
\hline $\begin{array}{l}\text { Executive } \\
\text { constraints }\end{array}$ & $\begin{array}{c}4.3 \\
(2.28)\end{array}$ & $\begin{array}{c}1 \\
(7)\end{array}$ & 1,353 & Polity IV & $\begin{array}{l}\text { Executive constraints, increasing } \\
\text { from } 1 \text { to } 7\end{array}$ \\
\hline CINC score & $\begin{array}{c}0.01 \\
(0.02)\end{array}$ & $\begin{array}{c}0 \\
(0.21)\end{array}$ & 1,275 & $\mathrm{CoW}$ & $\begin{array}{l}\text { Composite Index of National } \\
\text { Capability }\end{array}$ \\
\hline
\end{tabular}

Notes: WB = Group (2012); M\&R-Q = Montalvo and Reynal-Querol (2005); Solt = Solt (2009, 2016); QoG = Quality of Government database (Teorell et al., 2011); FH = FreedomHouse (2014); Polity IV = Marshall and Jaggers (2002); CoW $=$ Correlates of War (Singer and Stuckey, 1972). 